\title{
Nanocluster Mediated Photothermia Improves Eradication Efficiency and Antibiotic Sensitivity of Helicobacter Pylori
}

\section{Fansen Meng}

Department of Gastroenterology, The Second Medical Center \& National Clinical Research Center for Geriatric Diseases, Chinese PLA General Hospital

\section{Hongjin Tao}

Department of Gastroenterology, The Second Medical Center \& National Clinical Research Center for Geriatric Diseases, Chinese PLA General Hospital

Yan Mi

Department of Physics, Capital Normal University

\section{Tianyu Yang}

Department of Physics, Capital Normal University

\section{Xuanping Wang}

School of Medicine, Dentistry \& Biomedical Sciences, Queen's University Belfast

\section{Yuyo Go}

School of Medicine, Dentistry \& Biomedical Sciences, Queen's University Belfast

\section{Yunjuan Lin}

Department of Gastroenterology, The Second Medical Center \& National Clinical Research Center for Geriatric Diseases, Chinese PLA General Hospital

\section{Gangshi Wang ( $\square$ wanggangshi@hotmail.com )}

Department of Gastroenterology, The Second Medical Center \& National Clinical Research Center for Geriatric Diseases, Chinese PLA General Hospital

\section{Research Article}

Keywords: photothermal therapy, Zinc ferrite nanoclusters, helicobacter pylori, biofilm, antibiotic susceptibility

Posted Date: December 16th, 2021

DOI: https://doi.org/10.21203/rs.3.rs-1169549/v1

License: (9) This work is licensed under a Creative Commons Attribution 4.0 International License. Read Full License 


\section{Abstract}

Helicobacter pylori (H. pylori) eradication plays a crucial role in gastric cancer prevention, but the antimicrobial resistance of $\mathrm{H}$. pylori is obstructing this elimination process. In this study, we developed nanoclusters (NCs) from $\mathrm{Zn}_{0.3} \mathrm{Fe}_{2.7} \mathrm{O}_{4}$ nanoparticles using a poly(ethylene glycol)-b-poly( $\varepsilon$-caprolactone)based nanocarrier as an innovative antibiotic-independent $\mathrm{H}$. pylori management. The nanocluster showed minimal toxicity and maximal biocompatibility. With a low concentration $(50 \mu \mathrm{g} / \mathrm{mL})$ of NCs under a short time period $(\mathbb{2} 2 \mathrm{~min})$ of near-infrared $(808 \mathrm{~nm})$ irradiation, we kept the culture medium temperature to $41^{\circ} \mathrm{C}$ for 20 minutes with continuous irradiation. The heated NCs exhibited efficient photothermal effects and resulted in an excellent inhibition of $\mathrm{H}$. pylori growth, adhesion ability and cell vacuolization ability in in vitro investigation. Transmission electron microscopy showed a dramatic morphologic change after NCs photothermia on $\mathrm{H}$. pylori, including cell wall and membrane rupture, as well as ribosome damage. Besides, levofloxacin and clarithromycin resistance were improved after photothermal treatment in H. pylori NCTC 11637 and/or clinical strains, however metronidazole resistance was unchanged. We also discovered a significant decrease in the biofilm formation of $\mathrm{H}$. pylori under the NCs-based photothermal application, while efflux pump function was unchanged. In summary, using this novel NCs-based photothermal approach, we were able to demonstrate in vitro a significant inhibition of both $\mathrm{H}$. pylori growth and molecular toxicity, and its improvement in antibiotic resistance alone with the eradication of $\mathrm{H}$. pylori biofilms previously believed to be resistant to conventional antibiotics.

\section{Introduction}

Helicobacter pylori (H. pylori) is one of the most common human pathogens with an infection rate over $50 \%$ throughout the world [1-3]. H. pylori infection is clearly associated with a wide range of gastric pathologies, such as chronic gastritis, peptic ulcers, and gastric cancer / mucosa associated lymphoid tissue lymphoma $[2,4-7]$. Some studies have stated that $H$. pylori eradication may be the most practical way to reduce occurrence of gastric cancer and peptic ulcer disease and ultimately save lives, showing the importance of reliably successful eradication [8]. The rising rate of antibiotic resistance and the emergence of multidrug-resistant (MDR) H. pylori strains during the last decade has reduced the success of eradication therapy, and this can be partially attributed to extended and inappropriate use of antibiotics [9-11]. The World Health Organisation (WHO) has published a list of bacteria that urgently requires new antibiotics to overcome their current antibiotic resistance issues, and $H$. pylori is a high priority on the list [12]. Extensive research is being carried out on any innovative treatment.

One of these new antibiotics-independent approaches to eradicate $H$. pylori is the usage of nanotechnology. Light-based treatment has been used to utilize nanomaterials and their composites. Among them, photothermal therapy (PTT) has exhibited great potentials in dealing with drug-resistant bacteria and bacterial biofilms. In recent years, photothermal effect has been reported to possess high light-thermal conversion efficiency under the irradiation of near-infrared (NIR) light [13]. PTT has several advantages, such as being minimally invasive, remotely controllable and efficient, PTT is regarded as a 
safe and efficient strategy to manage bacterial infections [14,15]. Various mechanisms have been shown to contribute to antimicrobial resistance in $H$. pylori, such as genetic mutations, altered efflux pump activity, and the formation of bacterial biofilms [16]. While the field of $H$. pylori biofilm research is fairly new, groups have already begun to explore alternative therapeutic approaches that may target and eradicate bacterial biofilms including PTT [17]. PTT was reported to be efficient in treating biofilm-related infections and delayed the development of drug-resistant bacteria [18-21]. However, the effect of PTT on H. pylori biofilms remains to be elucidated.

In this study, we synthetized nanoclusters (NCs) from $\mathrm{Zn}_{0.3} \mathrm{Fe}_{2.7} \mathrm{O}_{4}$ nanoparticles (NPs) using a PEG-PCLbased nanocarrier, and compared its photothermal effects on $H$. pylori inhibition with NPs. We have also assessed their biological safety, as well as any alteration on antibiotic resistance of $H$. pylori after photothermal therapy. We have also assessed the underlying mechanisms of antimicrobial resistance, including changes in biofilm and efflux pump activity. As the first study of its kind, we have confirmed that the photothermal effect of NCs restrict the growth of $H$. pylori and improve antibiotic sensitivity, providing new ideas and methods for future $H$. pylori treatment.

\section{Materials And Methods}

\section{Materials}

H. pylori NCTC 11637, which was kindly provided by the H. pylori Strain Pool, Beijing, China, and two $H$. pylori clinical strains (27054 and L2) stored in our laboratory were used in this study. The following chemical materials were bought from Solarbio (China): Cell Count Kit-8, Dulbecco's Modified Eagle Medium (DMEM), Crystal Violet Stain solution (1\%), Hoechst 33342, fetal bovine serum (FBS), prussian blue iron stain kit, phosphate buffered saline (PBS), broth medium, trypsin, and penicillin/streptomycin $(10000 \mathrm{U} / \mathrm{mL})$. Campylobacter Agar Base were purchased from OXOID.

\section{Synthesis of $\mathrm{Zn}_{0.3} \mathrm{Fe}_{2.7} \mathrm{O}_{4} \mathrm{NPs}$}

$\mathrm{Zn}_{0.3} \mathrm{Fe}_{2.7} \mathrm{O}_{4} \mathrm{NPs}$ were synthesis by the thermal decomposition method [22]. First, $2.7 \mathrm{mmol}$ Iron(III) acetylacetonate $\left(\mathrm{Fe}(\mathrm{acac})_{3}\right), 0.3 \mathrm{mmol} \mathrm{Zinc}(\mathrm{II})$ acetylacetonate hydrate $\left(\mathrm{Zn}(\mathrm{acac})_{2} \cdot \mathrm{nH}_{2} \mathrm{O}\right), 2 \mathrm{mmol}$ sodium oleate, $4.4 \mathrm{~mL}$ oleic acid and $20 \mathrm{~mL}$ benzyl ether were added in a four neck flask and mixed by magnetically stirring. The mixture was heated to $120^{\circ} \mathrm{C}$ for $30 \mathrm{~min}$ with nitrgon flow. Under nitrigon blanketing, the mixture was heated to $295^{\circ} \mathrm{C}$ (reflux temperature), and kept refluxing for $2 \mathrm{~h}$. Finally, the mixture was cooled down to room temperature, and was treated by ethanol to precipitated out the NPs.

\section{Nanocluster Preparation}

Nanoclusters (NCs) loaded with $\mathrm{Zn}_{0.3} \mathrm{Fe}_{2.7} \mathrm{O}_{4} \mathrm{NPs}$ were prepared by the solvent evaporation method. 20 $\mathrm{mg} \mathrm{Zn}{ }_{0.3} \mathrm{Fe}_{2.7} \mathrm{O}_{4} \mathrm{NPs}$ and $50 \mathrm{mg} \mathrm{m}$-PEG-PCL were added in $8 \mathrm{~mL}$ of tetrahydrofuran (THF) then magnetically stirred for $20 \mathrm{~min}$. Next, the mixture solution was ultrasonicated for $20 \mathrm{~min}$. THF was then 
removed by rotary evaporation. The prepared aqueous solution was centrifuged at $3000 \mathrm{rpm}$ for $5 \mathrm{~min}$ and filtered through a $0.2 \mu \mathrm{M}$ cellulose acetate filter.

\section{Characterization of NPs and NCs}

The morphology of NPs was observed by a transmission electron microscope (Hitachi H-7650). The hydrodynamic particle size was measured using a dynamic light scattering instrument (Malvern ZS90 Red). Optical absorption spectra of the samples were recorded by using a UV-visible spectrophotometer (CARY 300 Conc.) with the wavelength range of $500-900 \mathrm{~nm}$.

\section{Photothermal efficiency}

To assess the photothermal efficiency of NPs and/or NCs, a diode laser with a power of $1000 \mathrm{~mW}$ and a wavelength of $808 \mathrm{~nm}$ was used to irradiate the dispersions of NPs or NCs. Different concentrations of NPs or NCs $(0,25,50 \mu \mathrm{g} / \mathrm{mL})$ dispersions diluted in $1 \mathrm{~mL}$ PBS in McBurney turbidimetric tubes were exposed to the laser light with a power density of $1.0 \mathrm{~W} / \mathrm{cm}^{2}$. PBS was selected as a control. The temperature rising of dispersions was recorded by thermometer. The temperature rising of dispersions was recorded by thermometer. The thermometer probe was placed vertically in the centre of the samples. The initial distance between laser source and PTAs liquids was $50 \mathrm{~cm}$. When the temperature of the system reached $40.5^{\circ} \mathrm{C}$, the distance was adjusted to around $80 \mathrm{~cm}$ to keep the temperature at $41^{\circ} \mathrm{C}$ constantly.

\section{Cell culture}

BGC-823 cells stored in our laboratory were used and maintained in DMEM//HIGH GLUCOSE medium containing $10 \%$ FBS and penicillin/streptomycin $(100 \mu \mathrm{g} / \mathrm{mL}$ penicillin and $100 \mu \mathrm{g} / \mathrm{mL}$ streptomycin) and cultured in a humidified atmosphere of $5 \% \mathrm{CO}_{2}$ at $37^{\circ} \mathrm{C}$.

\section{H. pylori culture}

H. pylori was cultivated on Campylobacter Agar Base with 7\% sheep blood in a microaerobic condition $(5 \% \mathrm{O} 2,10 \% \mathrm{CO} 2,85 \% \mathrm{~N} 2)$ at $37^{\circ} \mathrm{C}$. For liquid culture, the medium consisted of brucella broth contained $10 \% \mathrm{FBS}$ under agitating conditions $(120 \mathrm{r} / \mathrm{min})$ at $37^{\circ} \mathrm{C}$ in a microaerobic environment.

\section{Cytotoxicity of $\mathrm{Zn}_{0.3} \mathrm{Fe}_{2.7} \mathrm{O}_{4} \mathrm{NCs}$ on BGC-823 cells}

Cell Counting Kit-8 test was used to assess the cytotoxicity of $\mathrm{Zn}_{0.3} \mathrm{Fe}_{2.7} \mathrm{O}_{4} \mathrm{NCs}$ to BGC-823 cells. For the CCK-8 test, the BGC-823 cells were cultured in 96 -well plates at a density of $1 \times 10^{4}$ cells per well and were grown $10 \mathrm{~h}$ to stick to the wall ( $\mathrm{n}=5$ per group). Then, they were co-incubated with different concentrations $(0,25,50,100,200,250 \mu \mathrm{g} / \mathrm{mL})$ of $\mathrm{Zn}_{0.3} \mathrm{Fe}_{2.7} \mathrm{O}_{4} \mathrm{NCs}$ at $37^{\circ} \mathrm{C}$ for $24 \mathrm{~h}$ and $48 \mathrm{~h}$. After this step, wells were washed three times with PBS. Afterward, cells were incubated in media with $10 \%$ CCK- 8 solution ( $150 \mathrm{uL}$ ) at $37^{\circ} \mathrm{C}$ for $1 \mathrm{~h}$ in the dark. Following this period, the supernatant (100 uL) was 
transferred to a new plate to avoid the affect of NCs on optical density (OD) measurement. And finally, the absorbance was measured at $450 \mathrm{~nm}$ to quantify the cell growth.

\section{Prussian blue staining}

Prussian blue staining was used to assess the cellular uptake of $\mathrm{Zn}_{0.3} \mathrm{Fe}_{2.7} \mathrm{O}_{4} \mathrm{NCs}$ to BGC-823 cells. Different concentrations $(25,50,100 \mu \mathrm{g} / \mathrm{mL})$ of $\mathrm{Zn}_{0.3} \mathrm{Fe}_{2.7} \mathrm{O}_{4} \mathrm{NCs}$ were incubated with BGC-823 cells in 24- well plates at a density of $10^{5}$ cells per well ( $n=4$ per group). After $12 \mathrm{~h}$ or $24 \mathrm{~h}$ incubation, the cells were washed with PBS for three times, and then fixed with $4 \%$ paraformaldehyde. To stain the iron in cell, prussian blue solution, $2 \%$ hydrochloric acid aqueous solution and $2 \%$ potassium ferrocyanide (II) trihydrate were mixed, and then incubated with the fixed cells for 30 mins at $37^{\circ} \mathrm{C}$. Then, the cells were washed three times, and counterstained with nuclear eosin for $20 \mathrm{~s}$. Finally, the cells were observed by a microscope after washing three times with ultrapure water.

\section{Inductively coupled plasma mass spectrometry (ICP-MS)}

$\mathrm{Zn}_{0.3} \mathrm{Fe}_{2.7} \mathrm{O}_{4} \mathrm{NPs}$ or NCs were incubated with BGC-823 cells for $12 \mathrm{~h}$ or $24 \mathrm{~h}$ in 6 -well plates $\left(3 \times 10^{5}\right.$ cells per well). After this, cells were washed five times with PBS, and cells in all wells were collected as one sample ( $\mathrm{n}=3$ per group). Samples were digested with $\mathrm{HNO}_{3}$ and heated to $80^{\circ} \mathrm{C}$ for $3 \mathrm{~h}$ for ICP-MS analysis. The Fe content was measured using an Agilent Technologies 7700x inductively coupled plasma mass spectrometer (Agilent Technologies, Santa Clara,CA).

\section{Effect of $\mathrm{Zn}_{0.3} \mathrm{Fe}_{2.7} \mathrm{O}_{4} \mathrm{NCs}$ heating on $H$. pylori growth}

H. pylori in exponential growth phase was collected by PBS. $1 \mathrm{ml}$ mixture of $\mathrm{NCs}(50 \mu \mathrm{g} / \mathrm{mL})$ and $H$. pylori $\left(1 \times 10^{8} \mathrm{CFU} / \mathrm{mL}\right)$ was prepared in a McBurney turbidimetric tube. The tube was heated by with an $808 \mathrm{~nm}$ laser and the temperature of the mixture was recorded by a thermometer. $10 \mathrm{uL}$ of the mixture after the heating process was added to $3 \mathrm{~mL}$ broth medium and was cultured at $37^{\circ} \mathrm{C}$ for $96 \mathrm{~h}$. Then, the absorbance of each group was measured with a spectrophotometer (UV-2000, China) at $\mathrm{OD}_{600}$, which quantified the $H$. pylori survival rate. After heat treatment the mixture was diluted to $4 \times 10^{5} \mathrm{CFU} / \mathrm{mL}$ and each culturing agar medium was full of $100 \mathrm{uL}$ of the diluted mixture and cultured at $37^{\circ} \mathrm{C}$ for $96 \mathrm{~h}$. Finally, each group was counted to quantify the $H$. pylori survival rate.

\section{Transmission electron microscopy}

H. pylori in exponential growth phase was collected in PBS, and $1 \mathrm{ml}$ mixture of $\mathrm{NCs}(50 \mu \mathrm{g} / \mathrm{mL})$ and $H$. pylori $\left(1 \times 10^{8} \mathrm{CFU} / \mathrm{mL}\right)$ were prepared using McBurney turbidimetric tube and the tube was exposed to an $808 \mathrm{~nm}$ laserto heat the mixture to $41^{\circ} \mathrm{C}$ for $20 \mathrm{~min}$. After centrifugation for $4 \mathrm{~min}$ at $1500 \mathrm{r} / \mathrm{min}$, discarding the supernatant. Then, the bacterial was resuspended using a $2.5 \%$ glutaraldehyde fixation solution, and the bacteria was fixed at $4{ }^{\circ} \mathrm{C}$. After that, $10 \mu \mathrm{L}$ of bacterial liquid was dropped on the amorphous carbon-coated copper grids and allowed to dry. Then, one drop of $3 \%$ phosphotungstic acid dye solution was added for negative staining. Finally, samples were observed by TEM. 


\section{Evaluation of $H$. pylori adhesion ability and vacuolating cytotoxin}

H. pylori was collected in PBS and heated to $41^{\circ} \mathrm{C}$ for $20 \mathrm{~min}$. The bacteria were dissolved in DMEM/HIGH GLUCOSE medium without antibiotics and serum, to form H. pylori- DMEM/HIGH GLUCOSE solution $\left(\mathrm{OD}_{600}=0.1\right)$ for standby. For adhesion ability, BGC-823 cells were planked in a 96well plate with $1 \times 10^{4}$ cells/well, and cultured overnight. The above-mentioned bacteria liquid was added for co-cultivation with a ratio of bacteria: cells of 100: 1 for $2 \mathrm{~h}$. Then, discarding the supernatant and the cells were washed with PBS three times. Adding $100 \mu \mathrm{L}$ urea reagent into each well, and incubated for $2 \mathrm{~h}$ at room temperature. Finally, the absorbance of each group was measured with a spectrophotometer at a wavelength of $540 \mathrm{~nm}$. For vacuolating cytotoxin, BGC-823 cells were planked in 96 -well plate with $5 \times$ $10^{3}$ cells per well, and incubated at $37^{\circ} \mathrm{C}$ overnight. The above-mentioned bacteria liquid was added for co-cultivation for $24 \mathrm{~h}$ with a ratio of bacteria: cells of $200: 1$. The supernatant was discarded and $100 \mu \mathrm{L}$ neutral red $(0.005 \%)$ was added into each well for 5 minutes. Then, discarding the dye, and washing the cells with PBS three times, and $100 \mu \mathrm{L}$ hydrochloric acid alcohol $(0.04 \%)$ was added into each well. The absorbance of each group was measured with a spectrophotometer at a wavelength of $550 \mathrm{~nm}$.

\section{Assessment of $H$. pylori susceptibility to antibiotics}

MIC of various antibiotics for NCTC 11637 and all the clinical strains were measured by the Epsilometer test (E-test) using an E-strip (Liofilchem, USA). All the strains cultured in agar medium, and the thirdgeneration colonies were selected and suspended in PBS to an $\mathrm{OD}_{600}$ of 1 for standby. For control groups, above-mentioned bacteria solution were diluted to $\mathrm{OD}_{600}=0.1$ and $100 \mu \mathrm{L}$ of the bacterial solution was coated on Karmali Agar Base evenly. After each agar plate was left to dry, E-strip was affixed, and then the plates were incubated at $37^{\circ} \mathrm{C}$ under microaerobic conditions, and MIC values were determined after $72 \mathrm{~h}$. The method used to determine the MICs for heated groups was similar to that used for the control groups, $100 \mu \mathrm{L}$ of the bacterial solution $\left(\mathrm{OD}_{600}=1\right)$ was exposed to an $808 \mathrm{~nm}$ laser to heat to $41^{\circ} \mathrm{C}$ for $20 \mathrm{~min}$, then was evenly coated on Karmali Agar Baseto determine the MIC values.

\section{Crystal violet staining}

Biofilm formation was assessed under agitating conditions $(120 \mathrm{r} / \mathrm{min})$ in 12-well plates. H. pylori was collected by PBS and resuspended to an $\mathrm{OD}_{600}$ of 1 , and further diluted to $5 \times 10^{5} \mathrm{CFU} / \mathrm{mL}$ in broth medium and each was filled with $3 \mathrm{~mL}$ of the diluted bacterial solution and incubated at $37^{\circ} \mathrm{C}$ for 4 days. The plates were washed with PBS three times gently, and then stained with $500 \mu \mathrm{L}$ of $1 \%(\mathrm{w} / \mathrm{v})$ crystal violet for $30 \mathrm{~min}$. The crystal violet stain was solubilized with $80 \%$ ethanol- $20 \%$ acetone solution, and then measuring the absorbance at $\mathrm{OD}_{580}$. For experimental groups, the samples were heated with NIR to $41^{\circ} \mathrm{C}$ last for $20 \mathrm{~min}$, and the remaining steps were the same as above after a generation of cultivation.

\section{Confocal laser scanning microscopy (CLSM)}


CLSM was aimed at observing the biofilm as described with slight modifications [23]. A biofilm model of H. pylori was constructed in 6-well cell culture plate. Sterile cover glass with a diameter of $1 \mathrm{~cm}$ was put into 6-well plates, and $3 \mathrm{~mL}$ broth medium was added into each well. Then $10 \mu \mathrm{L} \mathrm{H}$. pylori solution with an $\mathrm{OD}_{600}$ of 1 was added into each well. The bacteria were cultured for 4 days in an incubator at $37^{\circ} \mathrm{C}$. The cover glass was removed, washed 3 times in PBS buffer to remove excess planktonic bacteria, and then moved into a new 6 -well plate and fixed in $2.5 \%$ glutaraldehyde at $4{ }^{\circ} \mathrm{C}$ for $1.5 \mathrm{~h}$. After washed with PBS, the fixed cover was added $300 \mu \mathrm{L}$ FITC-ConA $(100 \mathrm{mg} / \mathrm{mL})$ for 30 mins at $4{ }^{\circ} \mathrm{C}$ away from light, and PBS buffer was used to rinse slowly twice. Then, equal PI staining was performed in the same way and the cover glass was dried at room temperature away from light. Afterwards, the cover glass was sealed with anti-fade mounting medium, then observed under a laser confocal microscope. Five fields of the slides were randomly selected for shooting.

\section{Hoechst 33342 accumulation assay}

Accumulation assay was performed as described previously [24]. H. pylori was collected by PBS and resuspended to an $\mathrm{OD}_{600}$ of 1 , Then, $180 \mu \mathrm{L}$ of this bacteria solution was added to 96 -well plate. The excitation and emission wavelengths were 355 and $460 \mathrm{~nm}$ respectively, using SpectraMax M5/M5e (USA). After adding Hoechst $33342(25 \mu \mathrm{M}, 20 \mu \mathrm{L}) 5 \mathrm{~min}$, recordings were started. Readings were taken every $75 \mathrm{~s}$ for 30 cycles, and each experiment was repeated three times. For experimental groups, the samples were heated with NIR to $41^{\circ} \mathrm{C}$ for $20 \mathrm{~min}$, and the remaining steps were the same as above after a generation of cultivation.

\section{Statistical analyses}

Statistical analysis was carried out using GraphPad Prism (GraphPad Software, Inc., San Diego, CA, USA). All data were present as mean \pm standard errors of the means and determined using Student's $t-$ test. For all analyses, $p$ values $<0.05$ were considered significant, and the level of significance was described as ${ }^{*} p<0.05,{ }^{*} \mathrm{p}<0.01,{ }^{* *} \mathrm{p}<0.001$.

\section{Results}

\section{Synthesis and Characterization of Nanoclusters}

The NPs were synthesized by the one-pot thermal decomposition method, and the nanoclusters were prepared by a solvent evaporation method. Fig. 1a is the transmission electron microscopy (TEM) of $\mathrm{Zn}_{0.3} \mathrm{Fe}_{2.7} \mathrm{O}_{4} \mathrm{NPs}$ deposited on an amorphous carbon coated $\mathrm{Cu}$ grid. The average diameter of monodisperse $\mathrm{Zn}_{0.3} \mathrm{Fe}_{2.7} \mathrm{O}_{4} \mathrm{NPs}$ was about $18 \mathrm{~nm}$ with a tight size distribution. The result of electron diffraction pattern shows that $\mathrm{Zn}_{0.3} \mathrm{Fe}_{2.7} \mathrm{O}_{4} \mathrm{NPs}$ have high degree of crystallinity with typical cubic spinel structure (Fig. 1b). Fig. $1 \mathrm{c}$ is the TEM image of $\mathrm{Zn}_{0.3} \mathrm{Fe}_{2.7} \mathrm{O}_{4} \mathrm{NCs}$ formed by PEG-PCL nanocarriers. The size distribution of nanocluster in aqueous solution was measured by dynamic light scattering, as shown in Fig. $1 \mathrm{~d}$. The nanoclusters have a hydrodynamic size of about $130 \mathrm{~nm}$ with a relative broad size 
distribution. Fig. 1e shows the optical absorption spectra of $\mathrm{Zn}_{0.3} \mathrm{Fe}_{2.7} \mathrm{O}_{4}$ NPs dispersion. The absorption curve exhibits a platform with relative high value at the wavelength from $750 \mathrm{~nm}$ to $850 \mathrm{~nm}$, indicating $\mathrm{Zn}_{0.3} \mathrm{Fe}_{2.7} \mathrm{O}_{4}$ nanoclusters with good photothermal performance in the first NIR biological window.

NPs or NCs in phosphate buffered saline (PBS) solution were exposed to $808 \mathrm{~nm}$ lasers to study the photothermal efficiency. The time required for the solution to rise to $41^{\circ} \mathrm{C}$ of NCs $(50 \mathrm{mg} / \mathrm{mL})$ and NPs $(50 \mathrm{mg} / \mathrm{mL})$ was $240 \mathrm{~s}$ and $300 \mathrm{~s}$, respectively. It took longer at lower concentrations $(25 \mathrm{mg} / \mathrm{mL})$ to reach to $41^{\circ} \mathrm{C}$, and PBS alone has no appreciable temperature rise (Fig. 1f). These results indicate that the photothermal converting efficiency of NPs or NCs dispersed in PBS solution is dose-dependent.

\section{Bio-safety evaluation of NCs and its heating effects on $\mathrm{H}$. pylori growth}

Cell Counting Kit-8 (CCK-8) assay indicated that when human gastric adenocarcinoma epithelial cells BGC-823 cells were cultured with various concentrations of NCs (range: $0-250 \mathrm{mg} / \mathrm{mL}$ ) for $24 \mathrm{~h}$ or $48 \mathrm{~h}$, cell viability was not affected until the concentration reached $200 \mathrm{mg} / \mathrm{mL}$. When the concentration reached $250 \mathrm{mg} / \mathrm{mL}$, an inhibitory effect on cell viability was observed (Fig. 2a). After co-culturing with NCs $(300 \mathrm{mg} / \mathrm{mL})$ for $48 \mathrm{~h}$, the BGC-823 cell counts decreased to $50 \%$ of that in the control group (Supplementary data Fig. S1).

Mammalian cell uptake and penetration of NCs and NPs were investigated: BGC-823 cells were cultured with different concentrations of NPs and NCs $(0,25,50,100 \mu \mathrm{g} / \mathrm{mL})$ for $12 \mathrm{~h}$ and $24 \mathrm{~h}$. In the NPs group, the cytoplasm was stained blue (indicating endocytosis) at $50 \mu \mathrm{g} / \mathrm{mL}$ at $12 \mathrm{~h}$, and at $25 \mu \mathrm{g} / \mathrm{ml}$ at $24 \mathrm{~h}$. The NCs group showed no cytoplasm staining at $100 \mu \mathrm{g} / \mathrm{mL}$ at $24 \mathrm{~h}$. The results demonstrated that, compared with NPs, NCs showed no internalization into gastric cancer cells even at a high concentration and long incubation time (Fig. 2b), which illustrated the bio-safety aspect of NCs as a photothermal hyperthermia agent. In addition to this experiment, we have incubated Prussian blue with NPs and NCs for $12 \mathrm{~h}$, after the washing process, both samples still desmonstrated blue color compared to the control group. This result proved that Prussian blue could penetrate PEG membrane and enter inside NCs, therefore when NCs infiltrated into cells they could be identified by dyed blue stainings (Supplementary data Fig. S2).

We further quantified the NCs and NPs cellular uptakes in BGC-823 cells by measuring iron (Fe) content, through inductively coupled plasma mass spectrometry (ICP-MS). After 24 hours, no significant difference in Fe content was observed between control group and NCs co-cultured group. In contrast, the ICP-MS showed a significant increase in the uptake of NPs in BGC-823 cells after $24 \mathrm{~h}$ of incubation, and Fe concentration was time-dependent (Supplementary data Fig. S3).

We then investigated the photothermal effects of NCs on H. pylori growth and bacteria toxicity. A NIR laser at $808 \mathrm{~nm}$ was applied to NPs and NCs to heat the solution. The real-time monitoring of temperature in the culture solution during the laser irradiation was performed using a thermometer placed in the solution. Bacterial colony counts and $\mathrm{OD}_{600}$ values measured by a spectrophotometer were used for representing the growth of bacteria. The growth inhibition rate of $\mathrm{H}$. pylori after NCs photothermia 
increased monotonically in a temperature-dependent and time-dependent way, as shown in Supplementary data Fig. S4. Based on the photothermal efficiency and cell uptake test results, we chose a concentration of $50 \mu \mathrm{g} / \mathrm{mL}$ NPs or NCs in the planktonic $H$. pylori cultures which were then applied with laser irritation to increase the temperature to $41^{\circ} \mathrm{C}$ for $20 \mathrm{~min}$. NCs heat treatment group showed a significant inhibition to growth of $H$. pylori, with the cell growth of $6.7 \%$ that of the control group $(\mathrm{n}=3, p$ $<0.001$ ) (Fig. 3a). NCs without NIR irradiation group and the $41^{\circ} \mathrm{C}$ water bath group had no influence on bacterial growth (Fig. 3a). The inhibitory efficiency of NCs group were superior to the NPs groups (Supplementary data Fig. S5). Two clinical H. pylori stains (No. 27054 and No. L2) treated by laser irradiated NCs heating also demonstrated similar results (Fig. 3b and 3c). It is also notable that $H$.

pylori growth inhibition after NCs heating was both concentration-dependent and time-dependent: the 50 $\mathrm{mg} / \mathrm{mL}$ group showed a better inhibitory effect than the $25 \mathrm{mg} / \mathrm{mL}$ group, and the inhibitory effect in 20 min group was higher than in the 10 min group (Fig. $3 d$ to $3 f$ ).

While $H$. pylori cells growth was inhibited, the bacterium itself experienced several changes limiting its toxicity. In $H$. pylori 11637, the NCs photothermia group showed significantly lower adhesion ability of $H$. pylori cells compared with the control group $(n=3, p<0.001)$. NC photothermia groups also exhibited less cell vacuolization, with a $29.2 \%$ reduction compared with the control group $(n=3, p<0.001)$ (Supplementary data Fig. S6).

\section{Effect of NCs photothermia on the morphology of $H$. pylori.}

The effects on the morphology of $H$. pylori by NCs photothermia can be visualized through TEM. In the control sample, typical appearances of the $H$. pylori bacteria can be seen, with most having intact outer and inner membrane, complete ribosomes, and uniform cytoplasm (Fig. 4, control). In the NCs photothermia sample, the addition of heat resulted in a partial disappearance and thinning and shrinking of the outer membranes, abnormal distribution or disappearance of internal structures such as ribosome, and leakage of cytoplasmic contents (Fig. 4, NCs + heating).

\section{Induced changes in antimicrobial susceptibility of $H$. pylori}

We tested NPs and NCs heating on H. pylori strains using the E-test strip, in order to test its susceptibility to antibiotics (levofloxacin, clarithromycin and metronidazole). The minimum inhibitory concentration (MIC) for levofloxacin of 11637 was $1.4 \mu \mathrm{g} / \mathrm{mL}$ (control group). After photothermal heating at $41^{\circ} \mathrm{C}$ for $20 \mathrm{~min}$, MIC of $H$. pylori to levofloxacin decreased to $0.3 \mu \mathrm{g} / \mathrm{mL}$ in the NPs group and $0.8 \mu \mathrm{g} / \mathrm{mL}$ in the NCs group, which were below the breakpoint of levofloxacin resistance $(1.0 \mu \mathrm{g} / \mathrm{mL})$ [25]. Two levofloxacin-resistant clinical strains were also tested (27054 and L2), they were no longer resistant to levofloxacin after photothermia process. The MIC for clarithromycin of a clarithromycin-resistant clinical stain (27054) decreased after phothermia, but the value was still above the breakpoint of resistance. $H$. pylori NCTC 11637 strain and clinical strain (L2) were sensitive to clarithromycin before the heating, and this did not change after photothermia (Table 1, Supplementary data Fig. S7). All of these clinical strains remained metronidazole-resistant before and after heating. 
Table 1. Summary of antibiotic susceptibility of $\boldsymbol{H}$. pylori strains under different conditions.

MIC Breakpoints

$(\mu \mathrm{g} / \mathrm{mL})[25]$ :

Levofloxacin:

Sensitive $(S) \leqq 1$,

Resistant (R) $\otimes 1$;

Clarithromycin:

$S \leqq 0.25, R \otimes 0.5$;

Metronidazole:

$S \leqq 8, R \otimes 8$.

Biofilm and efflux

pump function

test of $H$. pylori

after NCs

photothermia
H. pyloristrain Antibiotics

P. pyloristrain Antibiotics

$\operatorname{MIC}(\mu \mathrm{g} / \mathrm{mL})$

Control NPs NCs

$\varangle 41^{\circ} \mathrm{C} 20 \mathrm{~min} \rrbracket \quad \nabla 41^{\circ} \mathrm{C} 20 \mathrm{~min} \rrbracket$

11637

Levofloxacin $\quad 1.4$

0.3

0.8

Clarithromycin

$0.125-0.25$

$0.125-0.25$

$0.125-0.25$

Metronidazole $₫ 256 \quad \varangle 256 \quad$ 256

27054

Levofloxacin

1.1

0.8

0.5

\begin{tabular}{|c|c|c|c|c|}
\hline & Clarithromycin & $16-24$ & $8-12$ & $6-8$ \\
\hline & Metronidazole & 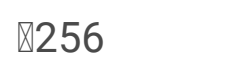 & $\varangle 256$ & 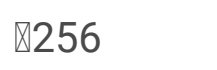 \\
\hline \multirow[t]{3}{*}{ L2 } & Levofloxacin & 1.2 & 0.7 & 0.5 \\
\hline & Clarithromycin & $0.125-0.25$ & $0.125-0.25$ & $0.125-0.25$ \\
\hline & Metronidazole & $\bigotimes 256$ & 『256 & $64-96$ \\
\hline
\end{tabular}

We therefore

investigated

whether biofilms alteration played a role in the decrease of H. pylori antimicrobial sensitivity in our NC experiments.

Crystal violet staining (Fig. 5a and 5b) and confocal laser scanning microscopy (CLSM) (Fig. 5c) were used to observe the changes of biofilms produced by NIR heating. Fig. 5a showed that biofilms were produced at the air-liquid interface on 12-well plates after 4 days of shaking culture in broth medium supplemented with $7 \%$ fetal bovine serum (FBS). Compared with the control group, the bacteria heated by NCs-based NIR produced less biofilms, and the two clinical strains were consistent with NCTC 11637.

Biofilms were quantified using a spectrophotometry-based approach, as in Fig. 5b, and the ratio of biofilm to biomass was significantly reduced in $\mathrm{H}$. pylori treated with NIR heating. We also compared the control group with the treatment group by CLSM (Fig. 5c). We added Fluorescein isothioyanate concanavalin A (FITC-ConA) and propidium iodide (PI) to both groups, and FITC-ConA would show green fluorescence where biofilm were formed, while PI would display red fluorescence when bacteria growth was detected. As can be seen in Fig. 5c, the control group has showed strong green fluorescence and formed large mature biofilms with compact structures. In the treatment group, the green fluorescence was weaker and the biofilms were discontinuous with larger apertures than the control group. Therefore, CLSM also indicated the photothermal effect of NCs exerted on $\mathrm{H}$. pylori biofilms, and this might be a significant factor in the change of drug sensitivity of $H$. pylori in the experimental group.

In addition, we explored whether the photothermal effect of NCs could affect the efflux pumps of $H$. pylori. As shown in Fig 6, we did not find any difference in accumulation of Hoechst 33342 between the experimental (NCs + heating) group and the control group, indicating that the photothermal effect of NCs 
has no effect on the function of efflux pumps, in contrast to the high fluorescence in CCCP group caused by suppressed efflux pump function.

\section{Discussion}

As the essential elements in PTT, photothermal agents can transform light energy into heat to cause membrane rupture, protein denaturation and irreversible bacterial destruction [26]. Metallic compound nanocomposites (metal sulfide/oxide) have been investigated as bactericidal agents, due to their source variety, high stability, semiconductor characteristics, good biocompatibility, easy preparation, low cost, and photothermal conversion efficiency. It is reported that low concentrations (10 mg/mL) of $\mathrm{ZnFe}_{2} \mathrm{O}_{4}-$ rGO nanostructures under NIR irradiation for a short time period ( $\mathbb{1} 1 \mathrm{~min}$ ) exhibited efficient photothermal effects and resulted in effective destruction of cancer cells in in vitro investigation [27]. This highlights the high thermal conversion efficiency of Zinc-iron oxide nanostructures, reports have also stated its excellent magnetic thermal conversion efficiency compared to ordinary $\mathrm{Fe}_{3} \mathrm{O}_{4}$ [22]. In this study, the photothermal effect of $\mathrm{NCs}$ tended to be more effective and efficient than that of NPs of $\mathrm{Zn}_{0.3} \mathrm{Fe}_{2.7} \mathrm{O}_{4}$. Zinc oxide nanoparticles have been researched for clinical applications, it demonstrated antiproliferation efficacy in A549 (human lung adenocarcinoma) cells, and with hyperthermia, they revealed cytotoxicity against breast cancer cells and bone cancer cells $[28,29]$. In addition, in vivo study to evaluate the efficacy of zinc oxide nanoparticles as an anti-tumor agent demonstrated that rats with hepatocellular cancer treated with zinc oxide had a significant reduction in serum tumor markers such as alphafetoprotein, relative to the control group [30]. The physiological gastric environment may be hostile to NCs due to its acidic nature, however, with the prescription of proton pump inhibitors (PPI) the environment can be adjusted to a neutral $\mathrm{pH}$ value (6-7) [31]. These results indicate the promising possibilities of photothermal therapy in clinical application. By clustering the nanoparticles, we believe that there will be an increased absorption of the indicated radiation, leading to a more efficient conversion of energy into heat than individual nanoparticles. Our results in this study demonstrated that $\mathrm{Zn}_{0.3} \mathrm{Fe}_{2.7} \mathrm{O}_{4}$ NCs exhibited better photothermal performance than NPs did. Similar biocompatible nanoclusters were developed, with CoMn-iron oxide nanoparticles clustered inside a poly(ethylene glycol)-b-poly $(\varepsilon$ caprolactone) (PEG-PCL)-based nanocarrier. The nanoclusters were found to be safe and exhibited high heating efficiency, which can elevate the intratumoral temperature to $44^{\circ} \mathrm{C}$ in the presence of a safe alternating magnetic field [32].

Reliable biosafety in the human body is essential for any treatment. Good PTAs should have minimal toxicity and maximal biocompatibility. Iron oxide nanoparticles (IONs) stand out as suitable for PTT because of their biocompatibility, biodegradability, simple synthesis, and the ease with which they may be adapted and functionalized for specific applications [33]. Despite the potential of PTT in antibacterial use, its non-specific heat damage to nearby tissues is potentially concerning. Unlike intracellular hyperthermia of tumors when internalization of nanoparticles into cells is crucial [40], it is important to avoid adjacent tissue damage during antibacterial applications. This will require prevention of individual nanoparticles being endocytosed by gastrointestinal mucosa cells. In this study, we evaluated bio-safety 
by its invasion on mammalian cell viability and penetration. In order to minimize nonspecific heating of healthy tissues, we proposed a controlled clustering of nanoparticles, which will increase the hydrodynamic size of the particles and in turn reduce the chance of internalization into adjacent cells. As studies have successfully demonstrated nanoparticles up to 5-10 mm entering human tissue, there does not seem to be an absolute limit in size that prevents internalization [34]. That being said, a smaller nanoparticle is generally considered to have a faster internalization than larger particles with the same charge and clinical composition, one study stated that nanoparticle will encounter difficulty entering cells when the size is greater than $60 \mathrm{~nm}$, due to cellular receptor shortage and entropic penalty [35-37]. Focusing specifically on gastric cells, smaller polysterene nanoparticles $(44 \mathrm{~nm})$ showed a faster and higher proportion of internalization than larger polysterene nanoparticles $(100 \mathrm{~nm})$ [38]. Therefore, by clustering the nanoparticles, we theorised a reduced internalization into adjacent tissues, thus leading to a lower risk of non-specific heating. The ICP-MS results confirmed that NCs could not penetrate into cells easily and demonstrated good biosafety, and this was consistent with our Prussian blue staining findings. These findings could be explained by the size of NCs (ours is $130.1 \pm 5.2 \mathrm{~nm}$ ) which made it difficult to penetrate mammalian cell membrane.

Declining eradication rates of $H$. pylori worldwide related to antimicrobial resistance have inspired a switch from antibiotic-based regimens to novel therapeutic strategies such as nanoparticle-based approaches. In recent years, nanomaterials have exhibited great potential in the growth inhibition of $H$. pylori $[39,40]$. Besides, the photothermal anti-H. pylori effect of nanomaterials was evaluated effectively in vitro and in vivo [41]. In this study, H. pylori growth was significantly inhibited after NCs photothermia, while TEM visualized outer wall rupture and ribosomal damage of $H$. pylori cells, which can be indicative of the antibacterial effects of this therapy. H. pylori adhesion ability is particularly crucial for its virulence, since adhesion molecules on its surface are responsible for mucin binding, leading to gastric mucosa invasion [42]. Vacuolization is also significant in H. pyloris toxicity, vacuolating cytotoxin (VacA) itself is a major virulence factor [43]. In our study, the NCs photothermia groups showed significantly lower adhesion ability of $H$. pylori cells and reduced cell vacuolization compared with the blank control group. This shows nanoparticle photothermia could be an efficient method to combat $H$. pylori for potential clinical use, both on its growth restriction and on molecular toxicity inhibition.

Alteration of antimicrobial susceptibility was reported after hyperthermia on Staphylococcus aureus, Escherichia coli, Pseudomonas aeruginosa, and our previous study found that NPs magnetic local heating could not only disrupt $H$. pylori cell directly, but could also enhance its susceptibility to amoxicillin, of which could be adopted for clinic applications readily [44-48]. One crucial mechanism of drug resistance is the formation of biofilms. Biofilms can be described as adherent aggregates of microorganisms encased in an extracellular polymeric substance (EPS), which contains proteomannans, LPS-related structures, extracellular DNA, proteins, and outer membrane vesicles [49, 50]. In addition, biofilms are associated with increasing mutations (to interfere with the antimicrobial activities), quorumsensing-regulated mechanisms and the activation of the general stress response. This activity makes it difficult to achieve effective antibiotic activity [51]. H. pylori is a biofilm-producing bacteria: it forms biofilms on the surface of the gastric mucosa (adopting the biofilm mode of growth to the mucosa and 
glands and can cover up to $97.3 \%$ of cell surface) and it displays resistance to antibiotics including clarithromycin [50]. Specifically, the MIC increased 16 -fold and the minimum bactericidal concentration increased by up to 4 -fold in biofilm cells compared to planktonic ones [44]. In general, relatively little is known in the field of $H$. pylori's biofilm structure and genes, and the therapies aiming to dissolve biofilms are still in their infancy [52]. Our findings provide a novel way to target $H$. pylori antibiotic resistance by the inhibition of biofilm formation.

Carbonyl cyanide m-chlorophenylhydrazone (CCCP), as a transmembrane proton gradient-collapsing agent, is a frequently used proton-transporting ionophore that transmits protons to disrupt transmembrane electrochemical gradient and inhibits the efflux pumps driven by hydrogen ion gradients, and thus restoring the antibiotic sensitivity of bacteria, including $H$. pylori $[53,54]$. Hoechst 33342 , a fluorescent probe, is a substrate for a wide range of bacterial multidrug resistance transporters $[24,55]$, it can penetrate into $H$. pylori and can be extruded by efflux pump, thus its fluorescence represents not only the amount of Hoechst 33342 in the bacteria, but also the efficiency of efflux pump too. The involvement of efflux pump in multidrug resistance of $H$. pylori has been identified [56-59]. There is no evidence in this study that the function of efflux pumps was affected by NCs photothermia, however, the thinning of the outer membrane may be indicative of the mechanism behind increased antimicrobial sensitivity and the growth inhibition of H. pylori.

There was potential limitation to this measurement: although the temperature of the mixture was kept at $41^{\circ} \mathrm{C}$, the interior of NCs and NPs were likely to be much hotter than the macroscopic solution. Studies showed that the temperature around nanoparticles could be detected by using real-time molecular temperature probes and found to decrease exponentially with the increase of distance from the surface of nanoparticles [60]. Acute temperature monitoring of the immediate nanoenvironment around nanoparticles may help to optimize local temperature controls for physical and biomedical applications. As the cooperative effects of antibiotics and NCs heating may reduce the dose of antibiotics required in the eradication of H. pylori greatly, it will be of great interest to couple antibiotics with NCs which can be localized to gastric area and then optimize the synergistic effects. Besides, for the envision that this approach can be applied to clinic applications, in vivo studies are needed to investigate both the anti- $H$. pylori effects of NCs photothermia and its bio-safety.

\section{Conclusion}

In this study, we successfully designed NCs formed by PEG-PCL-based NPs and demonstrated antibacterial effect of NCs/NPs under NIR laser heating for the first time. We evaluated the bio-safety of NCs and NPs, finding that NCs have higher biosafety compared with NPs. We found that NCs could inhibit the growth of $H$. pylori significantly under NIR laser heating. In addition, after NCs local heating, we found MIC of $H$. pylori to levofloxacin and clarithromycin is decreased. Investigaing further, we demonstrated for the first time that the photothermal effect of NCs disrupted $H$. pylori biofilm formation in vitro. Considering the current data, our research provides a new method for treating $H$. pylori infection, especially for drug resistant strains. 


\section{Abbreviations}

CCCP, Carbonyl cyanide m-chlorophenylhydrazone; CLSM, confocal laser scanning microscopy; DMEM, Dulbecco's Modified Eagle Medium; EPS, Extracellular polymeric substance; E-test, Epsilometer test; FBS, fetal bovine serum; FITC-ConA, Fluorescein isothioyanate concanavalin A; H. pylori, Helicobacter pylori; ICP-MS, Inductively coupled plasma mass spectrometry; IONs, Iron oxide nanoparticles; NCs, Nanoclusters; NIR, Near-infrared; NPs, Nanoparticles; PCL, poly ( $\varepsilon$-caprolactone); PI, propidium iodide; PTAs, Photothermal agents; PTT, Photothermal therapy; TEM, Transmission electron microscopy. Min, minute. $\mathrm{H}$, hour. $\mathrm{S}$, second.

\section{Declarations}

\section{Acknowledgements}

The authors thank Dr. Niall Joudeh, School of Medicine, Dentistry \& Biomedical Sciences, Queen's University Belfast, United Kingdom for his valuable opinions and language editing.

\section{Authors' contributions}

F.S.M. carried out the $H$. pylori growth and antibiotics susceptibility experiments, performed biosafety testing and drafted the manuscript; H.J.T. performed biofilm tests; Y.M. and T.Y.Y. carried out the preparation and characterization of nanoclusters. Y.J.L. conducted the photothermal procedure. X.P.W. and Y.Y.G. performed interpretation and evaluation of the results and wrote the manuscript. G.S.W. designed and conceived of the study, participated in its coordination and revised the manuscript. G.S.W. had primary responsibility for final content. All authors read and approved the final manuscript.

\section{Funding}

This study was supported by National Natural Science Foundation of China (Grant number. 51471186, 51771124), Chinese PLA Healthcare Project (Grant number 18BJZ22) and National Clinical Research Center for Geriatric Diseases (Grant number NCRCG-PLAGH-2019015). The funder had no role in the study design, data collection, data analysis, data interpretation, or writing of the article.

\section{Availability of data and materials}

All data generated or analysed during this study are included in this published article and its supplementary information files.

\section{Competing interests}

The authors declare that they have no competing interests.

\section{Authors' information}


${ }^{1}$ Department of Gastroenterology, The Second Medical Center \& National Clinical Research Center for Geriatric Diseases, Chinese PLA General Hospital, Beijing, China. ${ }^{2}$ Department of Physics, Capital Normal University, Beijing, China. ${ }^{3}$ School of Medicine, Dentistry \& Biomedical Sciences, Queen's University Belfast, United Kingdom.

\section{References}

1. Mane SP, Dominguez-Bello MG, Blaser MJ, Sobral BW, Hontecillas R, Skoneczka J, Mohapatra SK, Crasta OR, Evans C, Modise T, Shallom S, Shukla M, Varon C, Mégraud F, Maldonado-Contreras AL, Williams KP, Bassaganya-Riera J (2010) Host-interactive genes in Amerindian Helicobacter pylori diverge from their Old World homologs and mediate inflammatory responses. J Bacteriol 192:3078-92.

2. Uemura N, Okamoto S, Yamamoto S, Matsumura N, Yamaguchi S, Yamakido M, Taniyama K, Sasaki $\mathrm{N}$, Schlemper RJ (2001) Helicobacter pylori infection and the development of gastric cancer. N Engl J Med 345:784-9.

3. Ierardi E, Giorgio F, Losurdo G, Di Leo A, Principi M (2013) How antibiotic resistances could change Helicobacter pylori treatment: A matter of geography? World J Gastroenterol 19:8168-80.

4. Kusters JG, van Vliet AH, Kuipers EJ (2006) Pathogenesis of Helicobacter pylori infection. Clin Microbiol Rev 19:449-90.

5. Rocha GA, Rocha AM, Gomes AD, Faria CL, Jr., Melo FF, Batista SA, Fernandes VC, Almeida NB, Teixeira KN, Brito KS, Queiroz DM (2015) STAT3 polymorphism and Helicobacter pylori CagA strains with higher number of EPIYA-C segments independently increase the risk of gastric cancer. BMC Cancer 15:528.

6. Parkin DM (2006) The global health burden of infection-associated cancers in the year 2002. Int J Cancer 118:3030-44.

7. McColl KE (2010) Clinical practice. Helicobacter pylori infection. N Engl J Med 362:1597-604.

8. Forman D, Graham DY (2004) Review article: impact of Helicobacter pylori on society-role for a strategy of 'search and eradicate'. Aliment Pharmacol Ther 19 Suppl 1:17-21.

9. Peake RW, Marsden DL, Bodamer OA, Gelb MH, Millington DS, Wijburg F (2016) Newborn Screening for Lysosomal Storage Disorders: Quo Vadis? Clin Chem 62:1430-1438.

10. Boyanova L, Hadzhiyski P, Kandilarov N, Markovska R, Mitov I (2019) Multidrug resistance in Helicobacter pylori: current state and future directions. Expert Rev Clin Pharmacol 12:909-915.

11. Kwon DH, Dore MP, Kim JJ, Kato M, Lee M, Wu JY, Graham DY (2003) High-level beta-lactam resistance associated with acquired multidrug resistance in Helicobacter pylori. Antimicrob Agents 
12. Tacconelli E, Carrara E, Savoldi A, Harbarth S, Mendelson M, Monnet DL, Pulcini C, Kahlmeter G, Kluytmans J, Carmeli Y, Ouellette M, Outterson K, Patel J, Cavaleri M, Cox EM, Houchens CR, Grayson ML, Hansen P, Singh N, Theuretzbacher U, Magrini N (2018) Discovery, research, and development of new antibiotics: the WHO priority list of antibiotic-resistant bacteria and tuberculosis. Lancet Infect Dis 18:318327.

13. Jaque D, Martínez Maestro L, del Rosal B, Haro-Gonzalez P, Benayas A, Plaza JL, Martín Rodríguez E, García Solé J (2014) Nanoparticles for photothermal therapies. Nanoscale 6:9494-530.

14. Liu G, Zou J, Tang Q, Yang X, Zhang Y, Zhang Q, Huang W, Chen P, Shao J, Dong X (2017) Surface Modified Ti(3)C(2) MXene Nanosheets for Tumor Targeting Photothermal/Photodynamic/Chemo Synergistic Therapy. ACS Appl Mater Interfaces 9:40077-40086.

15. Han D, Han Y, Li J, Liu X, Yeung KWK, Zheng Y, Cui Z, Yang X, Liang Y, Li Z, Zhu S, Yuan X, Feng X, Yang C, Wu S (2020) Enhanced photocatalytic activity and photothermal effects of cu-doped metalorganic frameworks for rapid treatment of bacteria-infected wounds. Applied Catalysis B: Environmental 261.

16. Cammarota G, Sanguinetti M, Gallo A, Posteraro B (2012) Review article: biofilm formation by Helicobacter pylori as a target for eradication of resistant infection. Aliment Pharmacol Ther 36:222-30.

17. Gurunathan S, Jeong JK, Han JW, Zhang XF, Park JH, Kim JH (2015) Multidimensional effects of biologically synthesized silver nanoparticles in Helicobacter pylori, Helicobacter felis, and human lung (L132) and lung carcinoma A549 cells. Nanoscale Res Lett 10:35.

18. Teng CP, Zhou T, Ye E, Liu S, Koh LD, Low M, Loh XJ, Win KY, Zhang L, Han MY (2016) Effective Targeted Photothermal Ablation of Multidrug Resistant Bacteria and Their Biofilms with NIR-Absorbing Gold Nanocrosses. Adv Healthc Mater 5:2122-30.

19. Yuan Z, Tao B, He Y, Mu C, Liu G, Zhang J, Liao Q, Liu P, Cai K (2019) Remote eradication of biofilm on titanium implant via near-infrared light triggered photothermal/photodynamic therapy strategy. Biomaterials 223:119479.

20. Şen Karaman D, Ercan UK, Bakay E, Topaloğlu N, Rosenholm JM (2020) Evolving Technologies and Strategies for Combating Antibacterial Resistance in the Advent of the Postantibiotic Era. Advanced Functional Materials 30.

21. Yu S, Li G, Zhao P, Cheng Q, He Q, Ma D, Xue W (2019) NIR-Laser-Controlled Hydrogen-Releasing PdH Nanohydride for Synergistic Hydrogen-Photothermal Antibacterial and Wound-Healing Therapies. Advanced Functional Materials 29. 
22. He S, Zhang H, Liu Y, Sun F, Yu X, Li X, Zhang L, Wang L, Mao K, Wang G, Lin Y, Han Z, Sabirianov R, Zeng H (2018) Maximizing Specific Loss Power for Magnetic Hyperthermia by Hard-Soft Mixed Ferrites. Small:e1800135.

23. Takenaka S, Iwaku M, Hoshino E (2001) Artificial Pseudomonas aeruginosa biofilms and confocal laser scanning microscopic analysis. J Infect Chemother 7:87-93.

24. Coldham NG, Webber M, Woodward MJ, Piddock LJ (2010) A 96-well plate fluorescence assay for assessment of cellular permeability and active efflux in Salmonella enterica serovar Typhimurium and Escherichia coli. J Antimicrob Chemother 65:1655-63.

25. European-Committee The European Committee on Antimicrobial Susceptibility Testing. Breakpoint tables for interpretation of MICs and zone diameters.

1. Version 11.0, 2021. http://www.eucast.org.

26. Li J, Liu X, Tan L, Cui Z, Yang X, Liang Y, Li Z, Zhu S, Zheng Y, Yeung KWK, Wang X, Wu S (2019) Zinc-doped Prussian blue enhances photothermal clearance of Staphylococcus aureus and promotes tissue repair in infected wounds. Nat Commun 10:4490.

27. Akhavan O, Meidanchi A, Ghaderi E, Khoei S (2014) Zinc ferrite spinel-graphene in magnetophotothermal therapy of cancer. J Mater Chem B 2:3306-3314.

28. Kim S, Lee SY, Cho HJ (2018) Berberine and zinc oxide-based nanoparticles for the chemophotothermal therapy of lung adenocarcinoma. Biochem Biophys Res Commun 501:765-770.

29. Vimala K, Shanthi K, Sundarraj S, Kannan S (2017) Synergistic effect of chemo-photothermal for breast cancer therapy using folic acid (FA) modified zinc oxide nanosheet. J Colloid Interface Sci 488:92108.

30. Hassan HF, Mansour AM, Abo-Youssef AM, Elsadek BE, Messiha BA (2017) Zinc oxide nanoparticles as a novel anticancer approach; in vitro and in vivo evidence. Clin Exp Pharmacol Physiol 44:235-243.

31. Freedberg DE, Lebwohl B, Abrams JA (2014) The impact of proton pump inhibitors on the human gastrointestinal microbiome. Clin Lab Med 34:771-85.

32. Albarqi HA, Wong LH, Schumann C, Sabei FY, Korzun T, Li X, Hansen MN, Dhagat P, Moses AS, Taratula O, Taratula O (2019) Biocompatible Nanoclusters with High Heating Efficiency for Systemically Delivered Magnetic Hyperthermia. ACS Nano 13:6383-6395.

33. Revia RA, Zhang M (2016) Magnetite nanoparticles for cancer diagnosis, treatment, and treatment monitoring: recent advances. Mater Today (Kidlington) 19:157-168. 
34. Gratton SE, Ropp PA, Pohlhaus PD, Luft JC, Madden VJ, Napier ME, DeSimone JM (2008) The effect of particle design on cellular internalization pathways. Proc Natl Acad Sci U S A 105:11613-8.

35. Sahay G, Alakhova DY, Kabanov AV (2010) Endocytosis of nanomedicines. J Control Release 145:182-95.

36. Debbage P, Jaschke W (2008) Molecular imaging with nanoparticles: giant roles for dwarf actors. Histochem Cell Biol 130:845-75.

37. Hoshyar N, Gray S, Han H, Bao G (2016) The effect of nanoparticle size on in vivo pharmacokinetics and cellular interaction. Nanomedicine (Lond) 11:673-92.

38. Forte M, lachetta G, Tussellino M, Carotenuto R, Prisco M, De Falco M, Laforgia V, Valiante S (2016) Polystyrene nanoparticles internalization in human gastric adenocarcinoma cells. Toxicol In Vitro 31:12636.

39. Yang SJ, Huang CH, Yang JC, Wang CH, Shieh MJ (2020) Residence Time-Extended Nanoparticles by Magnetic Field Improve the Eradication Efficiency of Helicobacter pylori. ACS Appl Mater Interfaces 12:54316-54327.

40. Zhang J, Chen Z, Kong J, Liang Y, Chen K, Chang Y, Yuan H, Wang Y, Liang H, Li J, Mao M, Li J, Xing G (2020) Fullerenol Nanoparticles Eradicate Helicobacter pylori via pH-Responsive Peroxidase Activity. ACS Appl Mater Interfaces.

41. Zhi X, Liu Y, Lin L, Yang M, Zhang L, Zhang L, Liu Y, Alfranca G, Ma L, Zhang Q, Fu H, Conde J, Ding X, Chen D, Ni J, Song J, Cui D (2019) Oral pH sensitive GNS@ab nanoprobes for targeted therapy of Helicobacter pylori without disturbance gut microbiome. Nanomedicine 20:102019.

42. Huang Y, Wang QL, Cheng DD, Xu WT, Lu NH (2016) Adhesion and Invasion of Gastric Mucosa Epithelial Cells by Helicobacter pylori. Front Cell Infect Microbiol 6:159.

43. Palframan SL, Kwok T, Gabriel K (2012) Vacuolating cytotoxin A (VacA), a key toxin for Helicobacter pylori pathogenesis. Front Cell Infect Microbiol 2:92.

44. Alumutairi L, Yu B, Filka M, Nayfach J, Kim MH (2020) Mild magnetic nanoparticle hyperthermia enhances the susceptibility of Staphylococcus aureus biofilm to antibiotics. Int J Hyperthermia 37:66-75.

45. Ma M, Liu X, Tan L, Cui Z, Yang X, Liang Y, Li Z, Zheng Y, Yeung KWK, Wu S (2019) Enhancing the antibacterial efficacy of low-dose gentamicin with 5 minute assistance of photothermy at $50{ }^{\circ} \mathrm{C}$. Biomater Sci 7:1437-1447.

46. Fang CH, Tsai PI, Huang SW, Sun JS, Chang JZ, Shen HH, Chen SY, Lin FH, Hsu LT, Chen YC (2017) Magnetic hyperthermia enhance the treatment efficacy of peri-implant osteomyelitis. BMC Infect Dis 17:516. 
47. Nguyen M, Mikita G, Hoda RS (2016) "Intercellular bridges" in a case of well differentiated squamous carcinoma. Diagn Cytopathol 44:121-3.

48. Wu T, Wang L, Gong M, Lin Y, Xu Y, Ye L, Yu X, Liu J, Liu J, He S, Zeng H, Wang G (2019) Synergistic effects of nanoparticle heating and amoxicillin on H. pylori inhibition. Journal of Magnetism and Magnetic Materials 485:95-104.

49. Flemming HC, Wingender J, Szewzyk U, Steinberg P, Rice SA, Kjelleberg S (2016) Biofilms: an emergent form of bacterial life. Nat Rev Microbiol 14:563-75.

50. Hathroubi S, Servetas SL, Windham I, Merrell DS, Ottemann KM (2018) Helicobacter pylori Biofilm Formation and Its Potential Role in Pathogenesis. Microbiol Mol Biol Rev 82.

51. Høiby N, Bjarnsholt T, Givskov M, Molin S, Ciofu O (2010) Antibiotic resistance of bacterial biofilms. Int J Antimicrob Agents 35:322-32.

52. Yonezawa H, Osaki T, Kamiya S (2015) Biofilm Formation by Helicobacter pylori and Its Involvement for Antibiotic Resistance. Biomed Res Int 2015:914791.

53. Fanelus I, Desrosiers RR (2013) Mitochondrial uncoupler carbonyl cyanide Mchlorophenylhydrazone induces the multimer assembly and activity of repair enzyme protein Lisoaspartyl methyltransferase. J Mol Neurosci 50:411-23.

54. Zhang Z, Liu ZQ, Zheng PY, Tang FA, Yang PC (2010) Influence of efflux pump inhibitors on the multidrug resistance of Helicobacter pylori. World J Gastroenterol 16:1279-84.

55. van den Berg van Saparoea HB, Lubelski J, van Merkerk R, Mazurkiewicz PS, Driessen AJ (2005) Proton motive force-dependent Hoechst 33342 transport by the ABC transporter LmrA of Lactococcus lactis. Biochemistry 44:16931-8.

56. Bina JE, Alm RA, Uria-Nickelsen M, Thomas SR, Trust TJ, Hancock RE (2000) Helicobacter pylori uptake and efflux: basis for intrinsic susceptibility to antibiotics in vitro. Antimicrob Agents Chemother 44:248-54.

57. Liu ZQ, Zheng PY, Yang PC (2008) Efflux pump gene hefA of Helicobacter pylori plays an important role in multidrug resistance. World $\mathrm{J}$ Gastroenterol 14:5217-22.

58. van Amsterdam K, Bart A, van der Ende A (2005) A Helicobacter pylori TolC efflux pump confers resistance to metronidazole. Antimicrob Agents Chemother 49:1477-82.

59. Cai Y, Wang C, Chen Z, Xu Z, Li H, Li W, Sun Y (2020) Transporters HP0939, HP0497, and HP0471 participate in intrinsic multidrug resistance and biofilm formation in Helicobacter pylori by enhancing drug efflux. Helicobacter 25:e12715. 
60. Riedinger A, Guardia P, Curcio A, Garcia MA, Cingolani R, Manna L, Pellegrino T (2013)

Subnanometer local temperature probing and remotely controlled drug release based on azofunctionalized iron oxide nanoparticles. Nano Lett 13:2399-406.

\section{Figures}

a
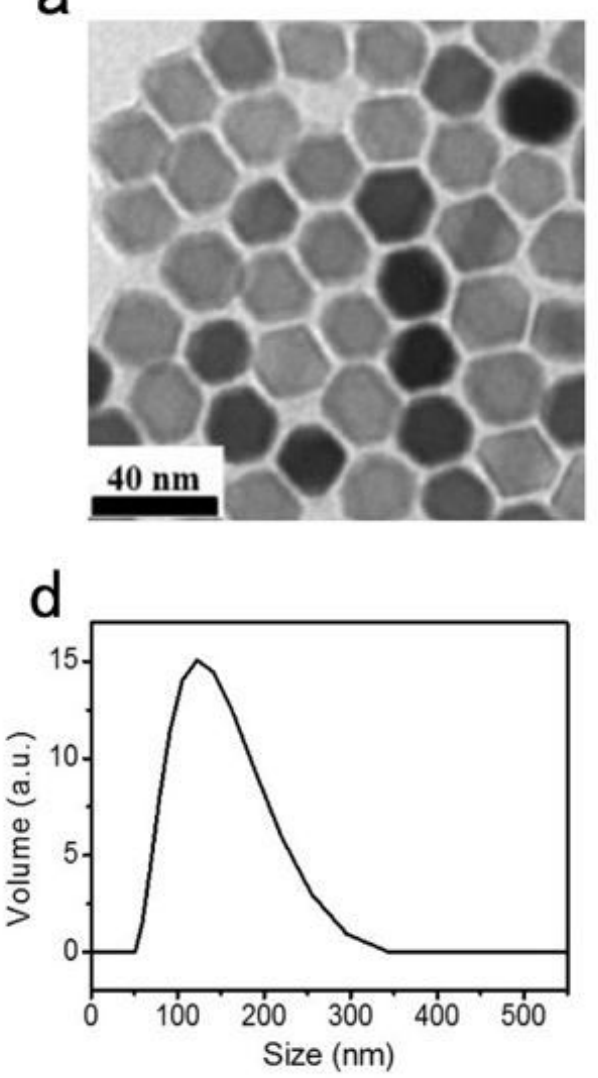

b

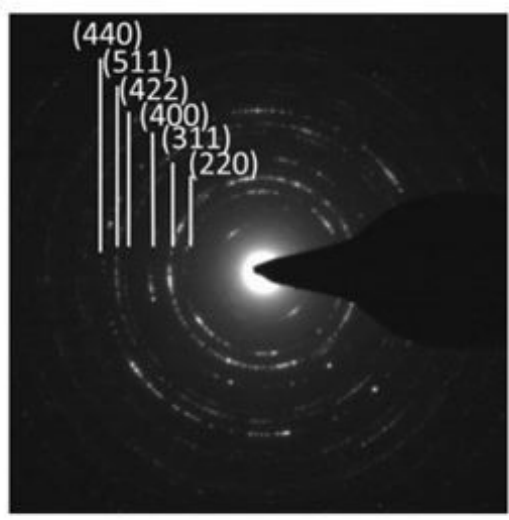

e

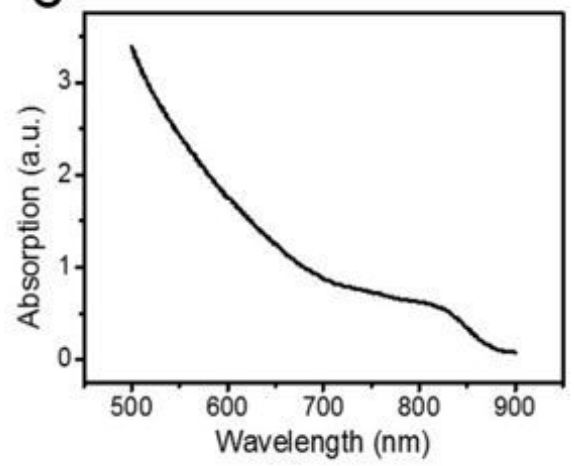

C
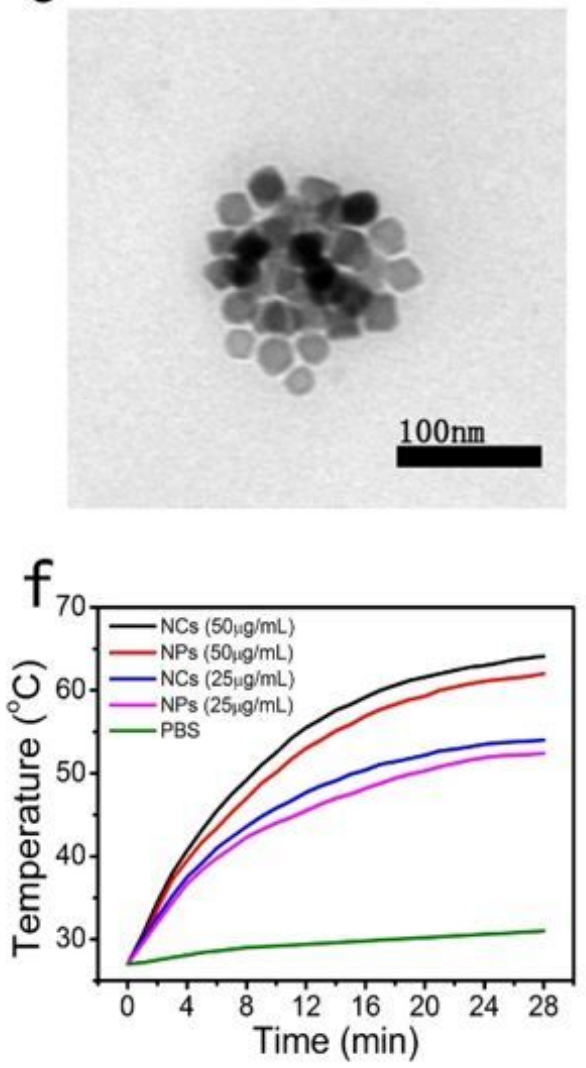

\section{Figure 1}

$<p><$ strong $>$ a $<$ /strong $>$ TEM image of monodisperse $\mathrm{Zn}<$ sub $>0.3</$ sub $>\mathrm{Fe}<$ sub $>2.7<$ /sub $>0<$ sub $>4$ $</$ sub $>$ NPs, with an average diameter of $18 \mathrm{~nm}$. $<$ strong $>b</$ strong $>$ electron diffraction showed typical cubic spinel structure. $<$ strong $>c</$ strong $>$ typical TEM image of $\mathrm{Zn}<$ sub $>0.3</$ sub $>\mathrm{Fe}<$ sub $>2.7</$ sub $>0<$ sub $>4</$ sub $>$ nanoclusters; $<$ strong $>\mathrm{d}</$ strong $>$ Size distribution of $\mathrm{Zn}<\mathrm{sub}>0.3</$ sub $>\mathrm{Fe}<\mathrm{sub}>2.7</$ sub $>0<$ sub $>4</$ sub $>$ nanoclusters tested by dynamic light scattering. $<$ strong $>$ e $<$ /strong $>$ Absorption spectra of $Z n<$ sub $>0.3</$ sub $>$ Fe $<$ sub $>2.7</$ sub $>0<$ sub $>4</$ sub $>$ nanoclusters. $<$ strong $>\mathrm{f}</$ strong $>$ Heating curves of different concentrations of NPs or NCs upon $808 \mathrm{~nm}$ laser irradiation. $</ p>$ 

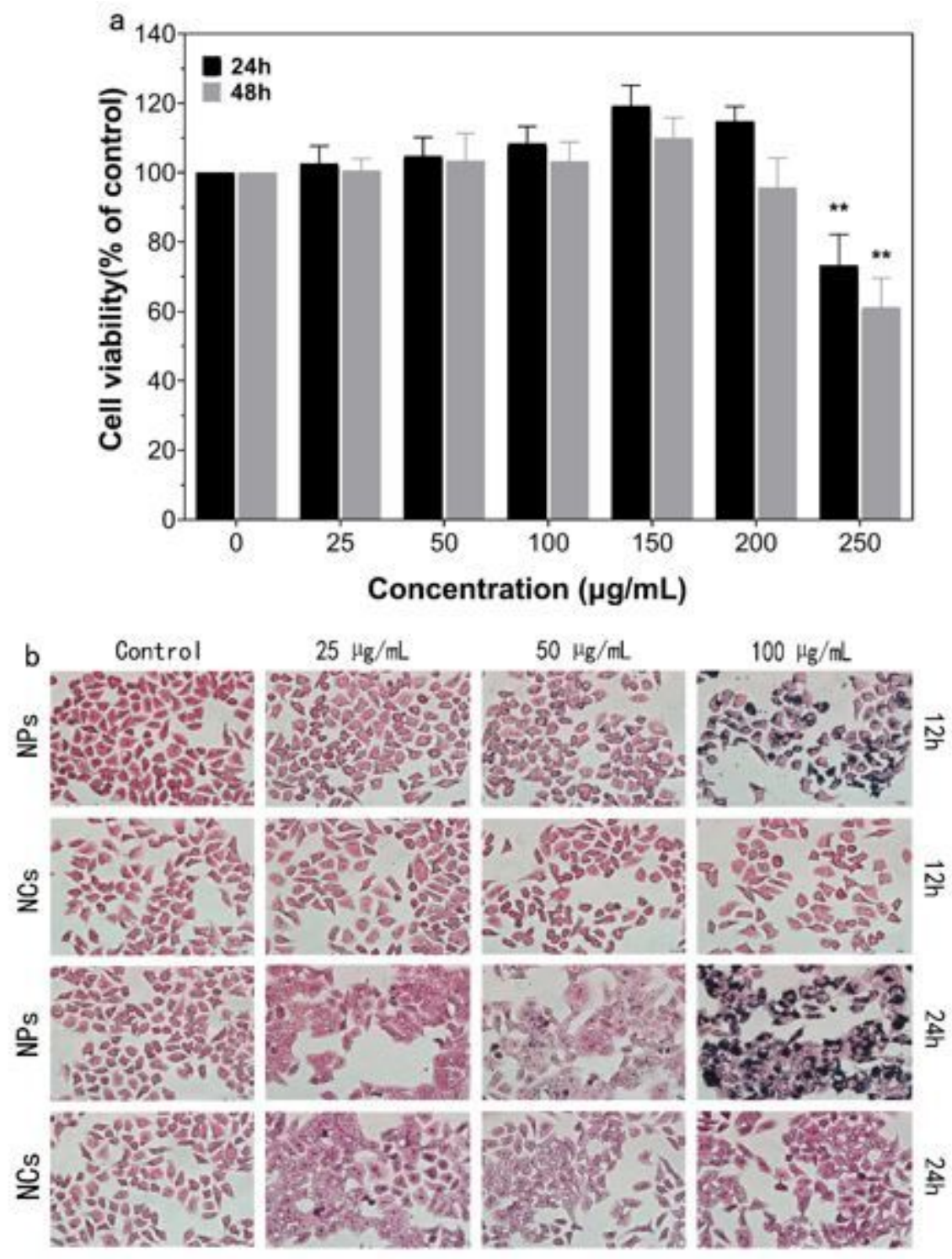

Figure 2

$<\mathrm{p}><$ strong $>\mathrm{a}<$ /strong $>$ The cytotoxicity of NCs to BGC-823 cells determined by CCK-8 assay. Cell viability was represented by optical density (OD) values measured by a spectrophotometer at a wavelength of 450 $\mathrm{nm}$. ** $<\mathrm{em}>\mathrm{p}</ \mathrm{em}>\& \mathrm{lt}$; 0.01, compared with $0 \mu \mathrm{g} / \mathrm{ml}$ group (control group); $<$ strong $>b</$ strong $>$ BGC-823 cells were incubated with NPs and NCs in the concentration range from 0 to $100 \mu \mathrm{g} / \mathrm{mL}$ for $12 \mathrm{~h}$ and $24 \mathrm{~h}$, respectively. The cells were stained blue in the NPs group at the concentration of $50 \mu \mathrm{g} / \mathrm{mL}$ at $12 \mathrm{~h}$, and $25 \mu \mathrm{g} / \mathrm{mL}$ at $24 \mathrm{~h}$. The NCs group showed no cytoplasm staining at the concentration tested. $(400 \mathrm{x})</ \mathrm{p}>$ 

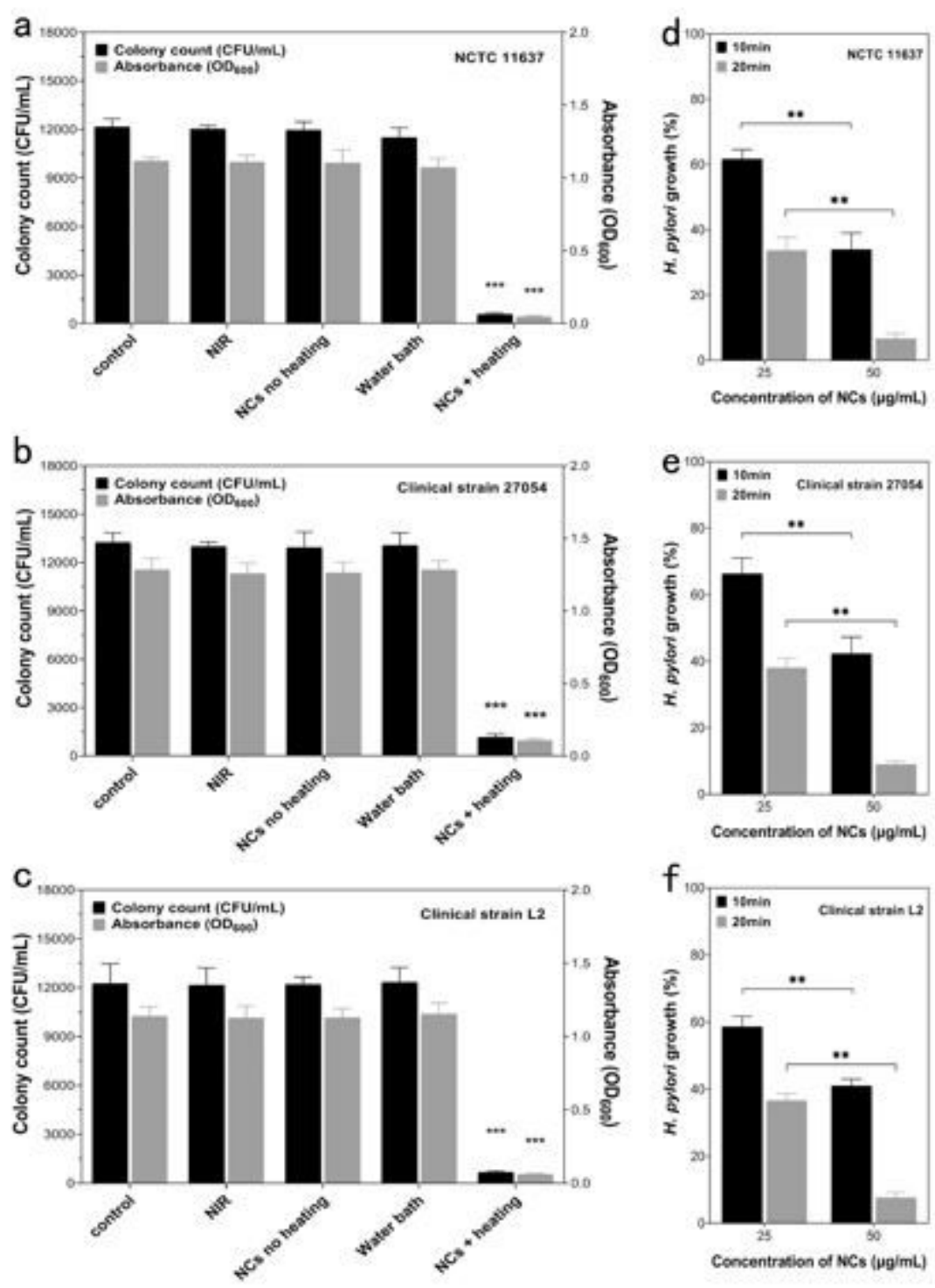

\section{Figure 3}

$<p>$ Effects of $\mathrm{Zn}<$ sub $>0.3</$ sub $>\mathrm{Fe}<$ sub $>2.7</$ sub $>0<$ sub $>4</$ sub $>$ NCs photothermia on the growth of $<$ em $>$ H. pylori</em>. Left panel: Growth of <strong $>a</$ strong $>$ NCTC 11637, $<$ strong $>b</$ strong $>$ clinical strain 27054, <strong $>$ c $<$ /strong $>$ clinical strain L2, after different treatment. $<\mathrm{em}>\mathrm{H}$. pylori </em>amount was measured by both Colony Count $(\mathrm{CFU} / \mathrm{ml})$ and Absorbance of $\mathrm{OD}<\mathrm{sub}>600</$ sub $>$. NCs plus heating group demonstrated significant inhibition effect on $<\mathrm{em}>\mathrm{H}$. pylori $</ \mathrm{em}>$ growth in all strains, $* \star \star$ $<\mathrm{em}>\mathrm{p}</ \mathrm{em}>\& \mathrm{It} ; 0.001$, compared with control. In contrast, interventions such as NIR, NCs without NIR irradiation, water bath at $41^{\circ} \mathrm{C}$, showed no growth inhibition. Right panel: Growth of <strong $>\mathrm{d}</$ strong $>$ NCTC 11637 , <strong $>$ e $<$ /strong $>$ clinical strain 27054 , <strong $>$ f $<$ /strong $>$ clinical strain L2 after different heating time and concentration of NCs. In equal heating time, NCs in higher concentration illustrated better $<\mathrm{em}>\mathrm{H}$. pylori $</$ em>inhibition effects. When the NCs concentrations were equivalent, more heating time equaled better effects. The group of $50 \mathrm{ug} / \mathrm{mL} \mathrm{NCs}$ photothermia at $41^{\circ} \mathrm{C}$ for $20 \mathrm{~min}$ exhibited the best efficiency $(n=3)$, ** $<$ em $>p</ e m>\& \mid t ; 0.01 . \& n b s p ;</ p>$ 

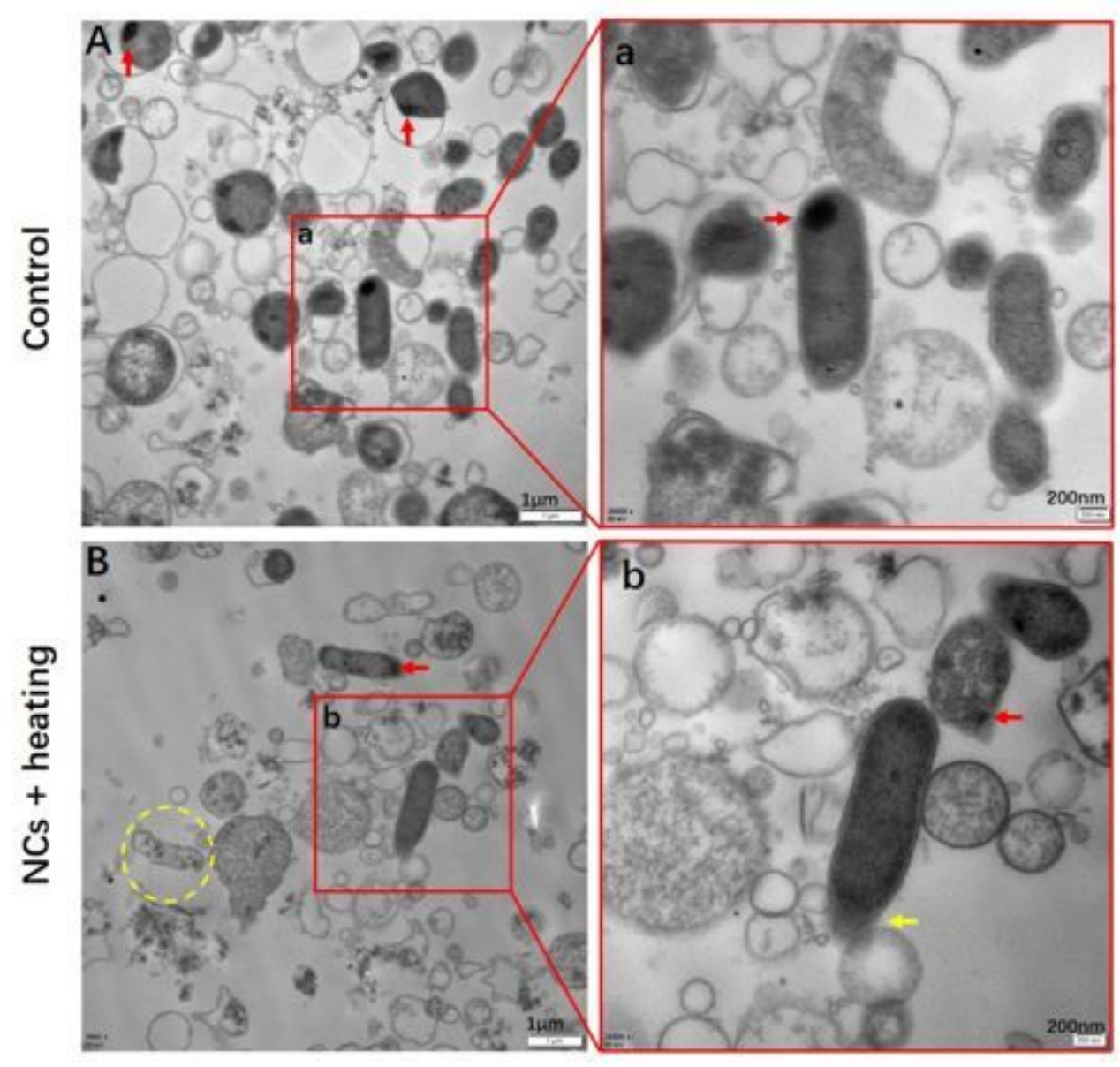

\section{Figure 4}

$<p>$ Effects of NCs heating on $<$ em $>\mathrm{H}$. pylori</em $>$ morphology under transmission electron microscopy observation. Upper lanes: control group, $<\mathrm{em}>\mathrm{H}$. pylori $</$ em>appeared in orderly distribution with intact cell wall and membrane. The cytoplasms were uniform with medium electron density. Ribosomes were intact as indicated by red arrows in Fig. 4A \&amp; Fig. 4a; Lower lanes: NCs heating group, <em>H. pylori $</$ em>were dispersed and disorganized. Yellow circle in Fig. 4B demonstrated distorted bacteria with thin and incomplete cell wall. Abnormal ribosome (red arrows in Fig. 4B \&amp; Fig. 4b) and leakage of cytoplasmic contents (yellow arrow in Fig. 4b) were observed. The red squares (Fig. 4a \&amp; 4b) demonstrated higher magnification of Fig. 4A \&amp; 4B, highlighted cell wall and membrane changes of individual $<$ em $>$ H. pylori. $</$ em $></ p>$ 
a Control NCs + heating

11637

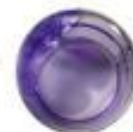

27054

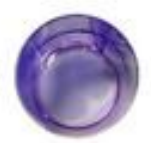

L2
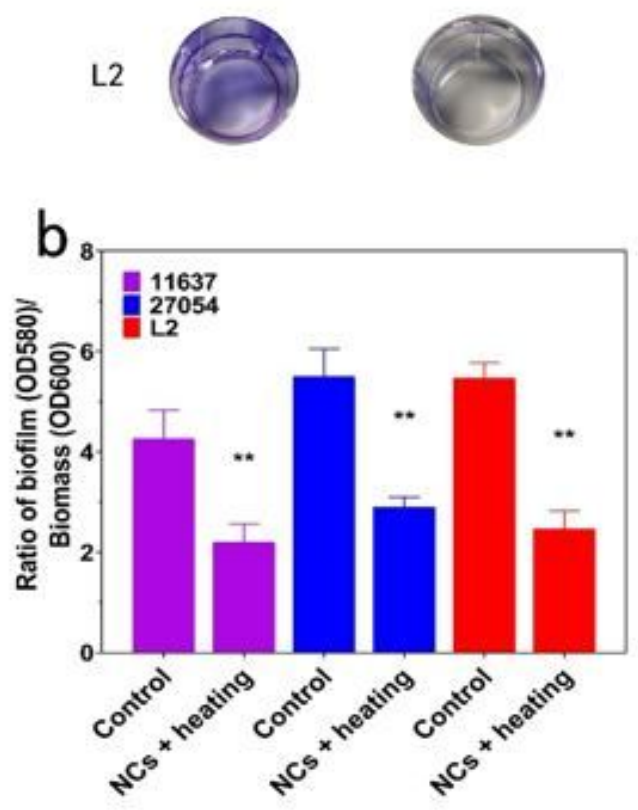
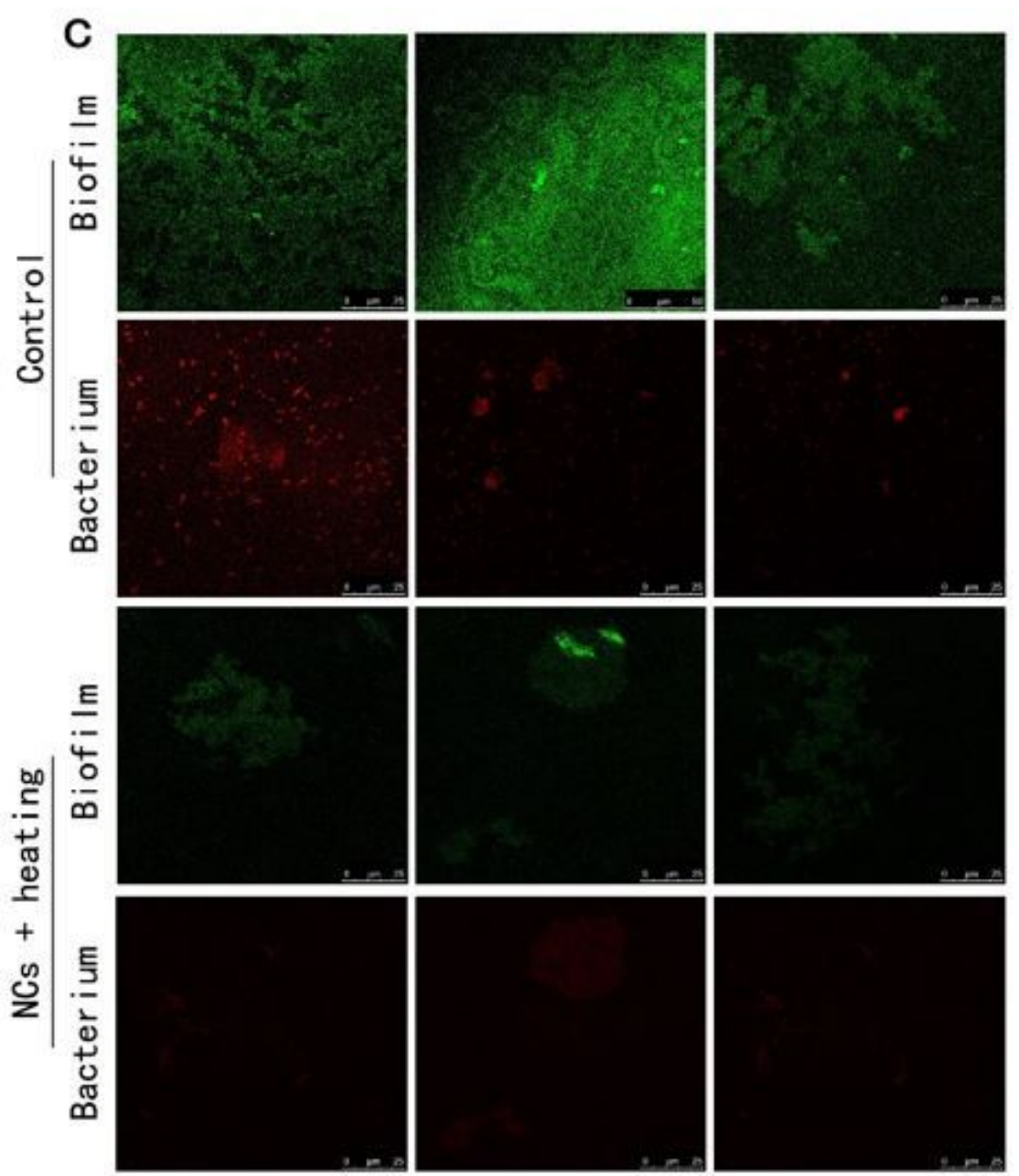

Figure 5

$<\mathrm{p}>$ Effects of photothermia on $<\mathrm{em}>\mathrm{H}$. pylori</em > biofilm formation. $<$ strong $>$ a $<$ /strong $>$ Macroscopic observation assessed by crystal violet staining in 24-well plate after 4 days of culture. Compared with control, no obvious violet signal was observed in the NCs + heating group, including $<\mathrm{em}>\mathrm{H}$. pylori $</$ em>NCTC 11637 as well as two clinical strains (27054 and L2). $<$ strong $>b</$ strong $>$ Changes of biofilm-to-biomass ratios of <em> H. pylori </em>NCTC 11637, clinical strain 27054 and L2. Bar graph represent mean biofilm-to-biomass ratios $(A<s u b>580</$ sub $>/ A<$ sub $>600</$ sub $> \pm$ standard error of the mean). ${ }^{*}<$ em $>p</$ em $>\& \mid t ; 0.01$, vs. the control group, $n=3$. $<$ strong $>c</$ strong $>$ Confocal laser scanning microscopy (CLSM) images of <em>H. pylori </em>NCTC 11637 strain biofilms. Cells stained with FITCConA (green) which represented the biofilm and PI (red) which represented bacterium were visualized by confocal microscopy $(400 x) .</ p>$ 


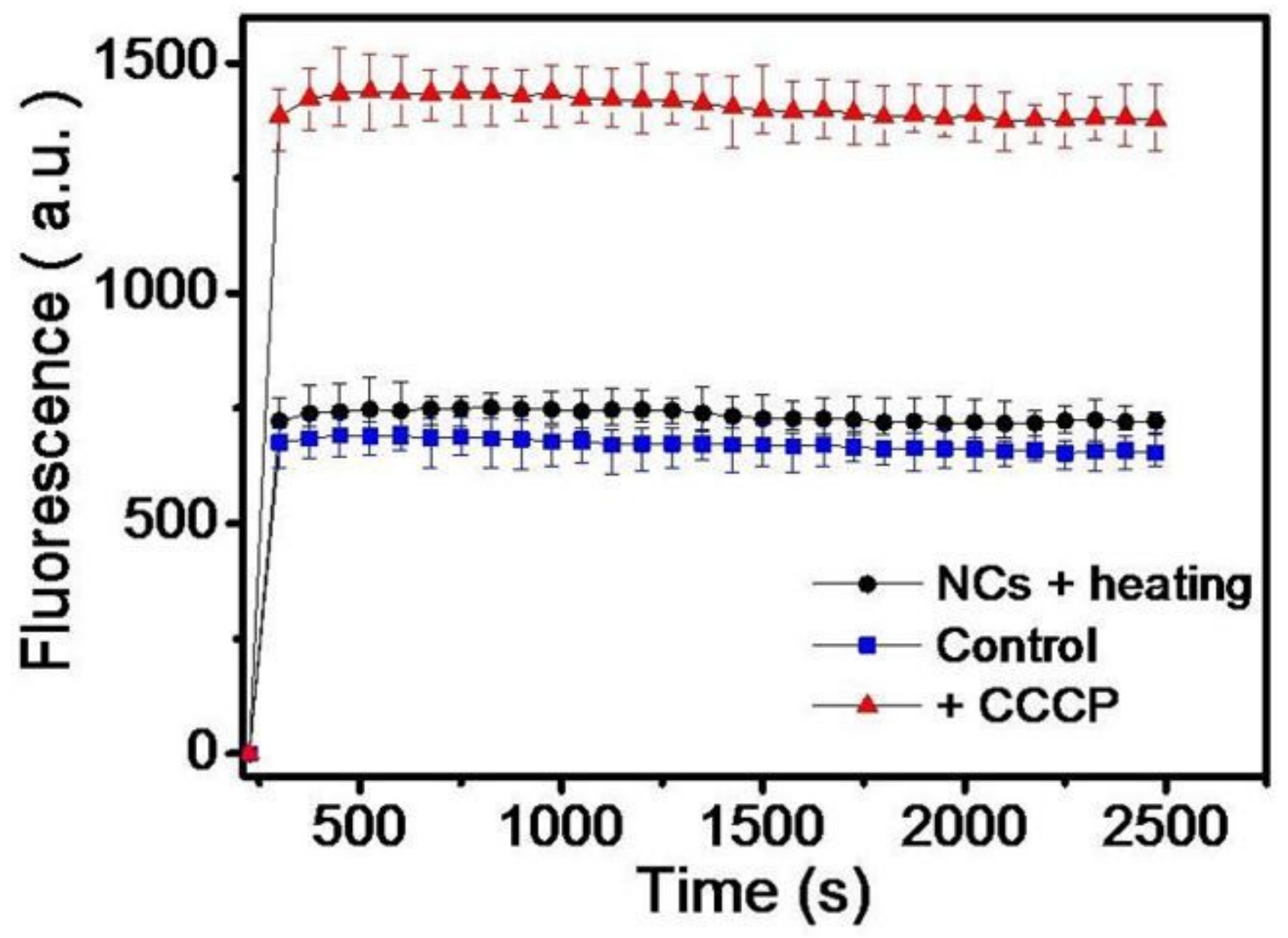

Figure 6

$<$ p $>$ Comparison of the accumulation of Hoechst $33342(2.5 \mathrm{M})$ in biofilm cells of the control, treated strains. Effect of efflux pump inhibitors CCCP $(10 \mathrm{mM})$ on the accumulation of Hoechst $33342(2.5 \mathrm{mM})$ by control, treated strains was used as positive control. The fluorescence intensity was recorded at excitation and emission wavelengths of $350 \mathrm{~nm}$ and $460 \mathrm{~nm}$, respectively, over a 30-min incubation period. The data presented are the means \pm standard errors of the means from three separate experiments.\&nbsp; $</ p>$

\section{Supplementary Files}

This is a list of supplementary files associated with this preprint. Click to download.

- SupplementaryFigures.docx 